Лукьянова Г. А., доктор ветеринарных наук, Перебийнис А. В., магистр, врач ветеринарной медицины

ЮФ НУБиП Украины «Крымский агротехнологический университет»

\title{
ВЛИЯНИЕ АКАРИЦИДНЫХ ПРЕПАРАТОВ РАСТИТЕЛЬНОГО ПРОИСХОЖДЕНИЯ НА КЛЕТОЧНЫЙ СОСТАВ ГЕМОЛИМФЫ ПЧЁЛ
}

\section{Рецензент - доктор ветеринарных наук В. В. Лемещенко}

Изучено действие различных растительных акарицидов (трава польни горькой, листья эвкалипта, дым корней хрена) на организм пчёл, а именно на клеточный состав гемолимфы. Обработки с использованием дыма корней хрена оказывают положительный эффект на нормализациию клеточного состава гемолимфы. Количество эночитоидов и платоцитов в гемолимфе пчёл семьи, инвазированной варроатозными клещзами, после обработки практически соответствовали физиологическим показателям. Акарищидные обработки с использованием травы польни горькой и листьев эвкалипта также имели положительный эффект, однако он был слабее. Наилучший эффект на показатели гемолимфограммы пчёл оказала обработка дымом корней хрена.

Ключевые слова: пчёль, гемоцииты, растительные акарицицды.

Постановка проблемы. Одним из важнейших условий поддержания гомеостаза организма животных является эффективное функционирование его иммунной системы. При паразитарных заболеваниях течение и исход болезни зависят от влияния паразита на иммунокомпетентную систему организма [2]. Как известно, в крови позвоночных животных действуют две независимые системы иммунитета - неспецифическая и специфическая. Неспецифический иммунитет обусловлен выделением в кровь антибактериальных белковых продуктов, создающих естественную или приобретенную устойчивость животных к заболеваниям, а также действием клеточных факторов защиты [3].

Анализ основных исследований и публикаций, в которых изложено решение проблемы. $\mathrm{У}$ насекомых неспецифическая система иммунитета тоже включает использование ферментов и форменных элементов гемолимфы - гемоцитов. Гемоциты медоносной пчелы делятся на плазматоциты, нимфоциты, сферулоциты, эноцитоиды и платоциты [4]. Гемоциты насекомых, как и позвоночных животных, обладают фагоцитозом. Функцию фагоцитоза выполняют у личинок и куколок платоциты и нимфоциты, а у взрослых пчел - платоциты.

Состав гемоцитов взрослых пчел не постоянен. Он изменяется в зависимости от возраста и состояния пчел, от сезона года, микрофлоры, от действия паразитов и лекарственных средств.

Например, у пчел, пораженных нозематозом, усиливается регенерация платоцитов. Поэтому у них наблюдается четкий сдвиг платоцитов в сторону увеличения количества молодых форм [5].

После освобождения от паразитов клеточный состав гемолимфы нормализуется с различной скоростью. Медленная нормализация может привести к быстрому заражению ослабленных пчёл другими возбудителями, например, инфекционной природы. Действие различных лечебных препаратов, которые применяются для обработок насекомых от возбудителей, на гемоформулу пчёл - неодинаково. В связи с этим важное значение приобретает изучение влияния акарицидов на численный состав гемоцитов.

Цель и задачи исследований. Цель исследования - установить клеточный состав гемолимфы пчёл, обработанных растительными акарицидными средствами. В задачи исследований входило определить изменения в гемоцитах пчёл при действии на их организм полыни горькой, листьев эвкалипта и корня хрена.

Материалы и методы исследований. Для опыта отобрали 20 пчелиных семей-аналогов и разделили их на 4 группы, по пять в каждой. Пчелы принадлежали к карпатской породе, объем гнезда - 20 рамок Лангстрота, возраст матоксестер один год, сила семей - 20 улочек, количество корма - 20 кг, экстенсивность инвазии II уровень, содержатся в ульях Лангстрота в одинаковых условиях на одной точке.

Обработку пчелиных семей акарицидами проводили 1 июня 2012 года.

Для обработки пчелосемей первой группы использовали порошок травы полыни горькой по 5 г на улочку. С этой целью полынь помещали в марлевый мешок на 14 дней, который расстилали тонким слоем на рамках над гнездом и накрыва- 
ли полиэтиленом.

В качестве акарицидного препарата для обработки пчелосемей второй группы применяли порошок листьев эвкалипта по 7,5 г на улочку. Его также помещали в марлевый мешок на 14 дней, расстилали тонким слоем на рамках над гнездом и накрывали полиэтиленом.

Третью группу пчелосемей окуривали дымом из высушенного корня хрена. С этой целью в разгоревшийся дымарь помещали 30 г корней хрена и делали по 1 дмуху на улочку в леток каждой семьи.

Четвёртая группа пчелосемей была контрольной, - обработкам препаратами не подвергалась.

В первых трёх группах на дно улья поместили листы белой бумаги, смазанные вазелином для фиксации осыпающихся варроатозных клещей. Замену листов проводили каждые 4 дня.

Действие акарицидных препаратов на организм насекомых оценивали по клеточному составу гемолимфы рабочих пчел.

Гемолимфу отбирали от 10 живых, только вышедших из ячейки пчел, в каждой семье на следующие сутки после окончания акарицидных обработок при помощи тонкой пипетки из синуса в области четвертого тергита брюшка согласно «Методическим рекомендациям по изучению средств и приёмов борьбы с клещом варроа» [1]. Гемолимфу наносили на предметное стекло и делали мазок, при этом для одного мазка испо- льзовали гемолимфу от одной пчелы. Приготовленные мазки высушивали на воздухе, после чего мазки фиксировали в этиловом спирте в течение 30 минут и окрашивали по методу Романовского-Гимзы. Окрашенные мазки просматривали под микроскопом, используя иммерсионный объектив. Гемоцитарную формулу определяли по общепринятой методике выведения лейкоформулы у животных. Использовали классификацию клеточных элементов гемолимфы, предложенную Б. А. Шишкиным [1]. Для сравнения гемоформул пчел использовали возрастной коэффициент гемолимфы (ВКГ), представляющий собой отношение числа старых клеток к числу зрелых и молодых [1].

Результаты исследований. Исследованием показателей клеточного иммунитета рабочих пчёл мы установили, что количественный состав гемоцитов после проведения акарицидных обработок в подопытных группах отличался (см. табл.).

Как видно из данных таблицы, наибольшее количество сферулоцитов наблюдали в I и III подопытных группах. Данной популяции клеток оказалось практически в два раза больше, чем в контрольной группе пчелиных семей, где количество сферулоцитов было наименьшим среди

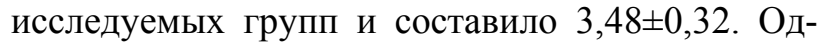
нако ни в одной подопытной группе численность сферулоцитов не совпадала с уровнем физиологической нормы.

Клеточный состав гемолимфы рабочих пчел, обработанных акарицидами

\begin{tabular}{|c|c|c|c|c|c|c|c|c|}
\hline \multicolumn{4}{|c|}{$\begin{array}{c}\text { Группы клеток } \\
\text { гемолимфы }\end{array}$} & Подопытная I & Подопытная II & Подопытная III & Контрольная & Норма [4] \\
\hline \multirow{18}{*}{$\begin{array}{l}\overrightarrow{\vec{E}} \\
\overrightarrow{\mid} \\
\overrightarrow{0} \\
\sum_{0}^{0}\end{array}$} & \multirow{5}{*}{ 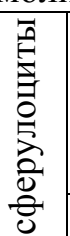 } & \multirow{4}{*}{ 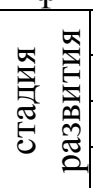 } & I & $0,1 \pm 0,2$ & $0,06 \pm 0,24$ & $0,1 \pm 0,3$ & $0,02 \pm 0,1$ & 1,3 \\
\hline & & & II & $3,5 \pm 1,8$ & $3,48 \pm 1,61$ & $3,2 \pm 1,6$ & $2,03 \pm 0,8$ & 6,2 \\
\hline & & & III & $3,2 \pm 2$ & $3 \pm 1,6$ & $3,6 \pm 2$ & $1,42 \pm 0,13$ & 6,2 \\
\hline & & & IV & $0,3 \pm 0,9$ & $0,2 \pm 0,53$ & $0,3 \pm 0,7$ & $0,01 \pm 0,4$ & - \\
\hline & & \multicolumn{2}{|c|}{ Всего } & $7,0 \pm 2,9$ & $6,74 \pm 2,42$ & $7,2 \pm 2,9$ & $3,48 \pm 0,32$ & 13,7 \\
\hline & \multirow{6}{*}{ 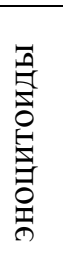 } & \multirow{5}{*}{ 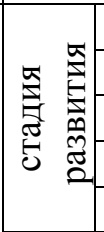 } & II & $1,2 \pm 0,9$ & $1,44 \pm 1,05$ & $2,2 \pm 1,3$ & $1,1 \pm 0,7$ & 2,8 \\
\hline & & & III & $1,5 \pm 1$ & $1,3 \pm 0,86$ & $2,3 \pm 1,2$ & $1,3 \pm 0,65$ & 0,1 \\
\hline & & & IV & $0,2 \pm 0,5$ & $0,22 \pm 0,46$ & $0,6 \pm 0,8$ & $0,13 \pm 0,04$ & 0,2 \\
\hline & & & $\mathrm{V}$ & $0 \pm 0,1$ & $0,04 \pm 0,2$ & $0,3 \pm 0,5$ & $0,02 \pm 0,1$ & 0,9 \\
\hline & & & VI & - & - & $0,2 \pm 0,4$ & - & 0,9 \\
\hline & & \multicolumn{2}{|c|}{ Всего } & $2,87 \pm 0,9$ & $2,96 \pm 1,05$ & $5,6 \pm 1,3$ & $2,55 \pm 0,21$ & 5,2 \\
\hline & \multirow{7}{*}{ 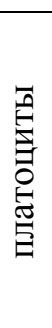 } & \multirow{6}{*}{ 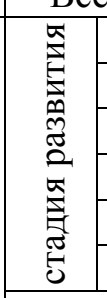 } & II & $17 \pm 4,8$ & $10,3 \pm 3,47$ & $4,8 \pm 2,6$ & $18,45 \pm 2,6$ & 7,9 \\
\hline & & & III & $30 \pm 5,6$ & $28,4 \pm 5$ & $25,0 \pm 5,9$ & $32,5 \pm 2,7$ & 30,3 \\
\hline & & & IV & $30 \pm 5,2$ & $33,3 \pm 4,61$ & $35,0 \pm 6,2$ & $35,7 \pm 2,2$ & 30,4 \\
\hline & & & $\mathrm{V}$ & $6,6 \pm 1,9$ & $10,2 \pm 4,02$ & $12,0 \pm 3,9$ & $12,71 \pm 1,43$ & 0,9 \\
\hline & & & VI & $3,6 \pm 1,7$ & $4,98 \pm 2,07$ & $6,5 \pm 2,4$ & $6,33 \pm 0,52$ & 0,9 \\
\hline & & & VII & $1,9 \pm 1,5$ & $2,98 \pm 1,71$ & $4,1 \pm 2,1$ & $3,87 \pm 0,18$ & 1,0 \\
\hline & & \multicolumn{2}{|c|}{ Всего } & $89,1 \pm 3,3$ & $90,16 \pm 2,79$ & $87,4 \pm 3,7$ & $91,11 \pm 1,64$ & 71,4 \\
\hline
\end{tabular}


Количество эноцитоидов наибольшим было в третьей группе пчелиных семей, и их числовое значение было в пределах физиологических показателей. При этом было отмечено наличие эноцитоидов VI стадии развития, тогда как численность аналогичных гемоцитов в первой и второй группах была на уровне поражённых варроатозными клещами пчёл.

При изучении численности платоцитов установили, что наибольшее число молодых и зрелых форм этих клеток имели рабочие пчелы после обработки порошком травы полыни горькой (I группа) и порошком листьев эвкалипта (II группа). Это указывает на активные регенеративные процессы в организме пчелы под воздействием применённых препаратов. В третьей группе пчелосемей (обработанных дымом корней хрена) численность платоцитов была заметно ниже по сравнению с другими группами, в том числе и с контрольной, но ещё не соответствовала физиологическим показателям.

\section{БИБЛИОГРАФИЯ}

1. Гулюкин М. И. Современные средства и методы обеспечения ветеринарного благополучия по инфекционной и протозойной патологии животных, рыб и пчел / М. И. Гулюкин, В. В. Субботин, Н. Л. Соколова [и др.] - М. : Россельхозакадемия, 2011. $-302 \mathrm{c}$.

2. Озеречковская H. Н. Органная патология в острой стадии тканевых гельминтов // Мед. паразитология. - 1999. - №1. - С. 3-12.
Таким образом, на основании проведённых исследований мы установили, что акарицидные обработки растительными препаратами способствуют изменению клеточного состава гемолимфы. Действие различных растительных акарицидов на организм пчёл отличается, о чём свидетельствуют изменения клеточного состава гемолимфы. В наших исследованиях наилучший эффект на нормализацию гемолимфограммы пчёл оказала обработка дымом корней хрена. Акарицидные обработки с использованием травы полыни горькой и листьев эвкалипта также имели положительный эффект, однако он был слабее.

Вывод. Акарицидные обработки с использованием дыма корней хрена оказывают положительный эффект на нормализацию клеточного состава гемолимфы. Количество эноцитоидов и платоцитов в гемолимфе пчёл семьи, инвазированной варроатозными клещами, после обработки практически соответствовали физиологическим показателям.

3. Ройт А. Иммунология: Пер. с англ. / Ройт А., Бростофф Дж., Мейл Д. - М. : Мир, 2000. - 592 с.

4. Таранов Г. Ф. Анатомия и физиология медоносных пчел / Таранов Г. Ф. - М. : Колос, 1968. $344 \mathrm{c}$.

5. Федорук $P$. Фактори формування імунітету медоносних бджіл / Р. С. Федорук, I. I. Ковальчук, А. Р. Гаварняк // Біологія тварин. - 2009. T. 11, № 1-2. - C. 83-90. 